Advances in Social Science, Education and Humanities Research, volume 411.

Copyright @ 2020 The Authors. Published by Atlantis Press SARL.

\title{
EXPLORING TEXTUAL FUNCTION REALIZATION IN CORRUPTION COURTROOM DISCOURSE
}

T. Silvana Sinar, T. Thyrhaya Zein, Nurlela, and Muhammad Yusuf

Faculty of Cultural Sciences, Universitas Sumatera Utara, Medan, Indonesia.

\begin{abstract}
This study deals with exploring the use of textual function in corruption courtroom discourse realized by Theme-Rheme structure in a clause uttered by judge, prosecutors, witness, and defender. Qualitative method was employed as the research design. The data were in the form of clauses gained from corruption courtroom discourse in Medan district court, Indonesia. The findings reveal that marked and unmarked themes were realized in the data. It is concluded that the sensitivity in choosing the markedness of theme is significant to be noted by judge, prosecutors, and others involved in the courtroom discourse since the creativity in conveying the utterances could be used to hide and blur the meaning.
\end{abstract}

Keywords: textual function, Theme-Rheme, markedness

\section{DISCLOSURE STATEMENT}

No potential conflict of interest was reported by the authors. 


\section{ACKNOWLEDGMENT}

The writers sincerely address their highest appreciation to the Ministries of Research, Technology and Higher Education of Indonesia for funding the research grant no 121/UN5.2.3.1/PPM/KPDRPM/2018.

\section{REFERENCES}

Betti, M. J., \& Hashim, T. G. (2018). The Lawyer's Discourse in the Courtroom: A Contrastive Study in English and Arabic. International Journal of English Linguistics, 8(3), 276-296. https://doi.org/10.5539/ijel.v8n3p276

Coulthard, M., \& Johnson, A. (2007). An Introduction to Forensic Linguistics: Language in Evidence. Routledge.

De Oliveira, L. C. (2015). A systemic-functional analysis of English language learners' writing. D.E.L.T.A., 31(1), 207-237. $\quad$ https://doi.org/dx.doi.org/10.1590/0102$\underline{4450364601799092306}$

Dong, J. (2013). Interpersonal Metaphor in Legal Discourse: Modality in Cross-examinations. Journal of Language Teaching and Research, 4(6), 1311-1321. https://doi.org/10.4304/j1tr.4.6.1311-1321

Eggins, S. (2004). An Introduction to Systemic Functional Linguistics (2nd ed.). Continuum.

Halliday, M. A. K., \& Matthiessen, C. M. I. M. (2004). An Introduction to Functional Grammar (3rd ed.). Hodder Education.

Jordan, S. N. (2002). Forensic linguistics: The linguistic analyst and expert witness of language evidence in criminal trials. [Master Thesis]. Biola University. 
Matin, S. A., \& Rahimi, A. (2014). Forensic discourse analysis: Legal speech acts in legal language'. Language Related Research, 4(4), 152-172.

McCabe, A., \& Heilman, K. (2007). Textual and interpersonal differences between a news report and an editorial. Revista Alicantina de Estudios Ingleses, 20(1), 139-156.

Miles, B. M., Huberman, A. M., \& Saldana, J. (2014). Qualitative Data Analysis: A Methods Sourcebook (3rd ed.). Sage Publication.

Naz, S., Alvi, S. D., \& Baseer, A. (2012). Political language of Benazir Bhutto: A transitivity analysis of her speech 'democratization in Pakistan.' Interdisciplinary Journal of Contemporary Research in Business, 4(8), 125-141.

Olsson, J. (2004). Forensic linguistics: An introduction to language, crime and the law. Continuum.

Sadiq, M. T. (2011). A discourse analysis of the language of investigation in the Kano Metropolis [Master Thesis]. Ahmadu Bello University.

Sinar, T. S. (2012). Teori \& analisis wacana pendekatan linguistik sistemik fungsional. Medan: Mitra Medan.

Sinar, T. S. (2018). Functional Features of Forensic Corruption Case in Indonesia. KnE Social Sciences, 3(4), 66-77. https://doi.org/10.18502/kss.v3i4.1919

Susanto, S. (2016, May). Language in Courtroom Discourse. In International Conference on Education and Language (ICEL) (p. 26).

Susanto, S., Zhenhua, W., Yingli, W., \& Nanda, D. S. (2020, January 13). Forensic Linguistic Inquiry into the Validity of F0 as Discriminatory Potential in the System of Forensic Speaker Verification. https://doi.org/10.31226/osf.io/4y6tn

Wang, Z. H. (2012). Forensic Linguistics (Vol. 8th). SJTU Press. 
Waskita, D. (2014). Transitivity in telephone conversation in a bribery case in Indonesia: A forensic linguistic study. 13(2), 91-100.

Zein, T. T., Sinar, T. S., Nurlela, N., \& Yusuf, M. (2019). The Incomplete Linguistic Features and Schematic Structure in EFL University Students' Narrative Texts. JETL (Journal Of Education, Teaching and Learning), 4(1), 203-209. https://doi.org/10.26737/jetl.v4i1.67 